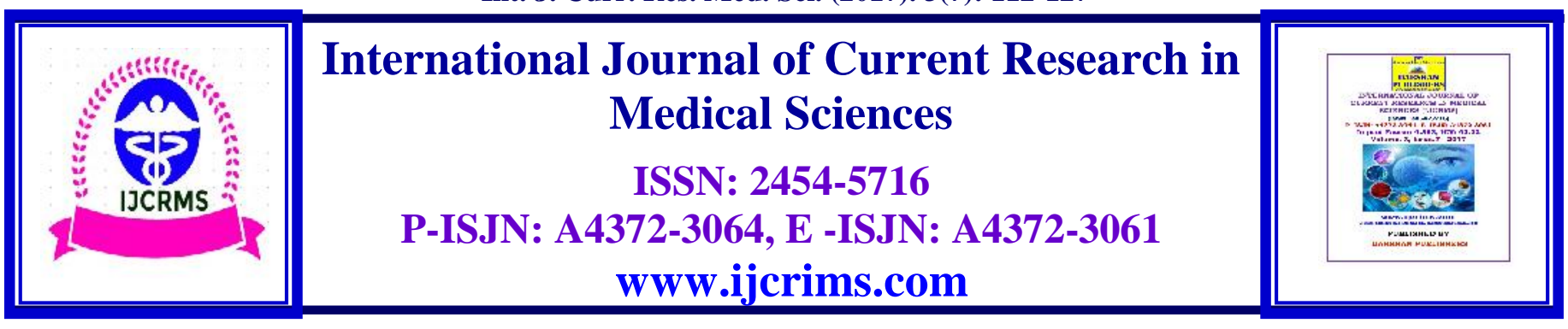

\title{
Standard Operative Procedure on External therapies in Siddha system of medicine
}

\author{
S.Mohamed Ajmal ${ }^{1}$, M.Naga lakshmi ${ }^{1}$, M.Nandhini ${ }^{1}$, G.Meenadharshini ${ }^{1}$, \\ P.J.Kowshika shree ${ }^{1}$, T.Keerthiga ${ }^{1}$, A.P.Uma ${ }^{2}$. \\ ${ }^{1}$ Final BSMS, Sivaraj Siddha Medical College, Salem-636307. \\ ${ }^{2}$ Lecturer Department of Sirappu maruthuvam, Sivaraj Siddha Medical College, Salem-636307. \\ *Corresponding author: mohamedajmal955@gmail.com,nagalakshmimuthumalai@gmail.com.
}

\begin{abstract}
The traditional Dravidian system of medicine referred to popularly as Siddha medicine is a vast repository of external therapies particularly administration of drugs through routes other than oral. These procedures are important in the management of health and disease. Great stress is laid by siddhars, the promoters of the medical system, on these procedures not only in prevention and cure of disease but also in promotion of health. The thirty two External therapies includes Ophthalmic application, Nasal application, Aural application, Oleation, Steam therapy, Physical manipulation therapies, Heat therapy, Other topical applications, Bone setting, Blood letting etc. Most of these therapies are aimed at maintaining a healthy balance of three humours (Tridosham), and also the seven tissue types of the body (Sapta dhatus). Some of the procedures need to be followed at regular frequency as a daily regimen or seasonal regimen to maintain this balance. Maximum efficacy of treatment is achieved by a judicious approach of using external therapies. This is the Hallmark of Siddha Medical Science. External therapies can be done in major measure with locally available resources and therefore is accessible as well as affordable to the entire society.
\end{abstract}

Keywords: Siddha medicine, External therapies, Tridosham, Sapta dhatus.

\section{Introduction}

Siddha Medicine is a vast repository of External therapies. In several instances, only the procedures without any drug are sufficient and these procedures are already systematized. Most of the therapies are aimed at maintaining healthy balance of the three physiological factors and also seven tissues of the body. There are occasions where administration of oral medicines becomes impossible and hence to revive the patient, administration of drugs or manipulation through external therapies like thokkanam, pattru, ottradam are required. Nasal application including inhalation and ophthalmic applications become important particularly in unconscious comatose patients, epilepsy, stroke patients and conditions like trauma, snake bite. It is very clear that the ancient physicians knew the connections between the brain and the sense organs and chose their routes and drugs accordingly ${ }^{(1)}$. Siddha Medicine is classified as Internal Medicines (Aga 
Marundugal 32) and External medicines (Pura marundugal 32) ${ }^{(2)}$. In Siddha system of Medicine, the term "Marundhu" is not exactly equivalent to the English 'drug'. "Marundhu" may be concrete or abstract. The abstract may be physical manipulation, heat or cold application, etc., Hence these non oral medicines are listed as External Medicines - 'Puramarundhu'. External therapy procedures are as important as in the management of Health and Disease. According to the mode of application, the siddha medicines could be categorized into two classes. Aga marunthugal/ Internal medicines were used through the oral route and further classified into 32 categories based on their form, methods of preparation, shelf - life, etc., Pura marunthugal/External medicines include certain forms of drugs and also certain applications (such as nasal, eye and ear drops), and also certain procedures (such as leech application). It is also classified into 32 categories $^{(3)}$. The 32 types of External therapies are as follows.

1. Kattu (Bandage)

2. Pattru (Poultice)

3. Poochu (Liquid application)

4. Kalimbu (Ointment)

5. Seelai (Medicated gauze)

6. Varthy (Medicated wick)

7. Pasai (Cream)

8. Kali (Paste)

9. Podi (Powder)

10. Neer (Medicated Liquid)

11. Nasiyam (Nasal drops)

12. Naasigabharanam (Insufflation)

13. Suttigai (Cautery/Heat application)

14. Ottradam (Fomentation)

15. Pugai (Fumigation)

16. Salaagai (Probe)

17. Oodhal (Blowing)

18. Mai (collyrium)

19. Kalikkam (Eye drops)

20. Urinchal (Suction)

21. Attai vidal (leech application)

22. Kuruthi vangal (Venesuction)

23. Murichal (Bone restructuring)

24.Kombukattal (Fracture splinting/ Immobilsation)

25. Thokkanam (Physical manipulation)

26. Podithimirdhal (Massage with dry powder)
27. Vedhu (Steam therapy)

28. Pottanam (Medicated pouch)

29. Aruvai (Excision)

30. Kaaram (chemical cautery)

31. Keeral (Incision)

32. Peechu (Douche) ${ }^{(3)}$

\section{Classification of external therapies}

- Topical Application

- Nasal Application

- Ophthalmic

- Blood letting

- Bone setting

- Physical Therapy

- Heat therapy

- Surgical procedures ${ }^{(1)}$

\section{Topical Application}

- Kattu (Bandage)

- Pattru (Poultice)

- Poochu (Liquid application)

- Kalimbu (Ointment)

- Seelai (Medicated gauze)

- Varthy (Medicated wick)

- Pasai (Cream)

- Kali (Paste)

- Podi (Powder)

- Neer (Medicated Liquid)

\section{Nasal Application}

- Nasiyam (Nasal drops)

- Naasigabharanam (Insufflation)

- Oodhal (Blowing)

\section{OphthalmicApplication}

- Mai (collyrium)

- Kalikkam (Eye drops)

\section{Blood letting}

- Urinchal (Suction)

- Attai vidal (leech application)

- Kuruthi vangal (Venesuction) 
Int. J. Curr. Res. Med. Sci. (2017). 3(7): 112-127

\section{Bone setting}

- Murichal (Bone restructuring)

- Kombukattal (Fracture splinting/Immobilsation)

\section{Physical Therapy}

- Thokkanam (Physical manipulation)

- Podithimirdhal (Massage with dry powder)

\section{Heat therapy}

- Vedhu(Steam therapy)

- Pottanam(Medicated pouch)

- Suttigai (Cautery)

- Ottradam (Fomentation)

- Pugai (Fumigation)

\section{Surgical procedures}

- Aruvai (Excision)

- Kaaram (Chemical Cautery)

- Keeral (Incision)

- Salaagai (Probe)

- Peechu (Douche) $)^{(3)}$

Shelf life of external medicines ${ }^{(3)}$

- Pasai, Peechu, Mai, Nasiyam, Kalikkam12months

- Varthy, Podi, Neer, Nasigabharanam-3 months

- Seelai, Kalimbu-6 months

\section{Materials and Methods}

\section{Topical Application}

\section{Kattu (Bandage)}

Kattu is applying a strip of materials such as cotton cloth with application of medicine made up of botanicals, inorganic substances (Pashanas) etc. in an affected site ${ }^{(3)}$.

\section{Therapeutic source}

Plant parts such as leaves, barks, egg yolk, curd, gingelly oil, breast milk, cow's butter, castor oil, cow's urine, mineral products.

\section{Eligible criteria}

Kattu is not advised in children below 3 years, pregnant women.

\section{Duration of the treatment}

The entire treatment is usually given for one time in a day at an interval of 3-7 days upto 3 Kattu.

\section{Indications}

Arthritis, Swelling, wounds, Achilles tendonitis, Calcaneal spur, Corn, Abscess, Bubo, Muscular sprain, Ano-rectal diseases, Scrotal swelling, Vertebral problems, Wounds, Carbuncle, Lymphedema.

\section{Kattu for various diseases ${ }^{(4)}$}

i. Grind the stem of Cissus quadrangularis (Pirandai), Leaves of Basella alba (Kodipasalai), Tender leaves of Delonix elata (Vatanarayanan), Leaves of Cardiospermum helicacabum (Mudakatran), Seeds of Trachyspermum ammi (Omam) and Resin of Shorea robusta (Vellaikungiliyam) is made into poultice and applied as kattu for Fracture.

ii. Fry the Flower of Justicia adhatoda (Adhathodai) with castor oil and applied as compressive bandage for the Eye diseases.

iii. Fry the Leaves of Dodonaea viscose (Virali) with castor oil and applied as compressive bandage for the Scrotal swelling.

\section{Pattru (Poultice)}

The Pattru is obtained from plant extracts or by grinding raw drugs with or without processing them. Normally the medicine to be applied is made into a thick paste and applied over the affected region $^{(1)}$.

\section{Therapeutic source}

Plant parts such as leaves, barks, egg yolk, breast milk, curd, cow's butter, castor oil, cow's urine, buffalo's urine, mineral products. 


\section{Eligible criteria}

Pattru is not advised in Cellulitis, children below 3 years.

\section{Duration of the treatment}

The entire treatment is usually given for one time in a day at an interval of 3-7 days upto 3 Patru.

\section{Indications}

Inflammation and boils, Arthritis, Elephantiasis, Swelling, wounds, Achilles tendonitis, Calcaneal spur, Corn, abscess, Heavy metal toxicity, Skin diseases, Stress, Bubo, Muscular sprain, Fistula, Hemorrhoids.

\section{Pattru for various diseases ${ }^{(4)}$}

i. Pound the Kaavikkal and sift them. Add the egg white into the Kaavikkal powder and make a fine paste to apply locally for Elephantiasis.

ii. Clean the pulp of Charakkondrai puli, remove the seed and soak into the water. Then mix the Vediuppu with the pulp and make the poultice by grinding them to apply locally over the abdomen for Scrotal swelling.

iii. Neerkovai maathirai pattru applied on fore head in case of headache or sinusitis.

\section{Poochu (Liquid application)}

Poochu is application of liquid formulation locally. Application of medicated oils or herbal juices or mixtures of powdered drugs ${ }^{(1)}$.

\section{Therapeutic source}

Plant parts such as leaves, barks, tubers, fruits, salts, limestone.

\section{Eligible criteria}

Pattru is not advised in Cellulitis, new borns.

\section{Duration of the treatment}

The entire treatment is usually given for 15 to 30 minutes, once in a day.

\section{Indications}

Arthritis, Headache, Disc prolapse, Calcaneal spur, Bronchitis, Asthma, Muscle spasm, Sprain, Psoriasis, Sinusitis, Bell's palsy, Vitiligo.

\section{Poochu for various diseases}

i. A poultice is made with the root of Acalypha indica, Amaranthus spinosus and Acorus calamus, added to sesame oil and boiled to prepare oil for the topical application of Carbuncle ${ }^{(5) .}$

ii. Myristica fragrans is charred and the carbon is mixed with the sesame oil and applied in Neogrowths ${ }^{(6)}$.

iii. The Coconut milk extracted from one half of the coconut kernel is mixed with slaked lime and applied for Scabies ${ }^{(3)}$.

\section{Kalimbu (Ointment)}

Kalimbu is defined as the buffer of oil and water, compound with specific drug powders.

\section{Therapeutic source}

Dry plant parts like leaves, flowers, butter, ghee,oil.

\section{Eligible criteria}

Kalimbu is not advised in Allergic persons.

\section{Duration of the treatment}

The entire treatment is usually given for 12 hours.

\section{Indications}

Alopecia, Skin ulcers, Lymphadenoma, Fissures, Hemorrhoids.

\section{Kalimbu for various diseases}

i. Terminalia chebula are powdered, ground with butter and applied over wounds and ulcers.

ii. Equal quantity of Mercuric chloride (Veeram) and Molten lead (Karuvangam) are triturated with clarified butter and applied on the skin for Tinea. Triturate 4.16gms of Calomel (Pooram) with $208 \mathrm{gms}$ of butter to fineness and obtain an 
Int. J. Curr. Res. Med. Sci. (2017). 3(7): 112-127

ointment. This ointment heals Non-healing ulcers $^{(7)}$.

\section{Seelai (Medicated gauze)}

This type of external medicine is in the form of medicated plasters. Plasters are prepared by grinding toxic materials in water or herbal juice. A piece of cloth is soaked in this and externally applied over wounds ${ }^{(3)}$.

\section{Therapeutic source}

Dry plant parts like leaves, flowers, butter, ghee, oil.

\section{Eligible criteria}

Seelai is not advised in infants, pregnant women, haemophilia.

\section{Duration of the treatment}

The entire treatment is usually given for 12 hours.

\section{Indications}

Alopecia, Skin ulcers, Lymph adenoma, Fissures, Hemorrhoids, Corns, Warts.

\section{Seelai for various diseases}

i. Dressings can be impregnated with antiseptic inorganic materials, as in borax (Vengaram) or castor oil was first used in the first surgical dressings (Karaseelai).

ii. The following gums such as Shorea robusta (Vellai kungiliyam), Commiphora mukkul (Erummaikan kungiliyam), Feronia elephantum (Vilaa), Vateria indica (Kundrikkam) provides adherence of ingredients to the cloth or gauze and are themselves act as antibacterial, antiinflammatory and antiseptic.

iii. Grind Copper sulphate in water and soak the cloth in it and apply it for non-healing ulcers.

\section{Varthy (Medicated wick)}

This type of external medicine is in form of medicated wicks. Caustic substances are ground well with herbal juices or decoctions, a piece of cloth is soaked in this and a wick is prepared.

\section{Therapeutic source}

Plant juices, salts, honey, fatty oil, ghee, honeybee wax.

\section{Eligible criteria}

Varthy is not advised in oral cavity, infants, allergic persons.

\section{Duration of the treatment}

The entire treatment is usually given for 6 hours.

\section{Indications}

Fissures, Hemorrhoids, Skin ulcers, Fistula, Sinus, Nasal bleeding, Constipation.

\section{Varthy for various diseases ${ }^{(6)}$}

i. Wicks can be prepared from honey and rocksalt and inserted into the anal orifice for Purgation.

ii. A wick is prepared with the poultice of equal quantity of the leaves of Achyranthes aspera, Curcuma longa and Piper nigrum with castor oil and the wick is introduced into the sinus of the wounds. The excessive flesh and unwanted growth will get reabsorbed and healing hastened.

iii. Salt, Piper nigrum and tender leaves of Azadirachta indica are made into a wick and applied on Abscess.

\section{Pasai (Cream)}

A semisolid lipid or resin / gum based applications, usually fats are used as bases, vegetable oils or bees wax. As with creams they are emollient and protective, but stay on the skin longer ${ }^{(3) .}$

\section{Therapeutic source}

Powdered plant parts like leaves, flowers, stem, wax, medicated oil. 
Int. J. Curr. Res. Med. Sci. (2017). 3(7): 112-127

\section{Eligible criteria}

Pasai is not advised in allergic persons.

\section{Duration of the treatment}

The entire treatment is usually given for 5-10 minutes.

\section{Indications}

Alopecia, Skin ulcers, Lymph adenoma, Fissures, Hemorrhoids.

\section{Pasai for various diseases}

i. Shells of fresh water mussel are heated on charcoal fire and dropped in the fresh juice of Emblica officinalis. The process is repeated for 35 times. The ash so obtained is triturated with castor oil till it attains waxy consistency. The ointment is useful in crack foot. Powder of White arsenic (Vellai paadaanam) is added to molten Bees wax and mixed well. This mezhugu is warmed and applied on Abscess and Bubo ${ }^{(8)}$.

\section{Kali (Paste)}

Medicinal materials are mixed with rice flour or flour of any cereals or pulses and cooked and applied on the affected site ${ }^{(3)}$.

\section{Therapeutic source}

Plants parts like cereals, grains, seeds, eggs.

\section{Eligible criteria}

Pasai is not advised in children below 5 years, pregnant women.

\section{Duration of the treatment}

The entire treatment is usually given for 3-6 hours.

\section{Indications}

Psoriasis, Dry eczema, Swelling, Abscess, Anorectal diseases, Scrotal swelling, Bubo, Carbuncle, Corn.

\section{Kali for various diseases ${ }^{(7)}$}

i. In case of Abscess, Rice flour and Turmeric are ground well with water, heated, made into paste and applied over it.

ii. Make a poultice by grinding together with hot water, 20.8gms each of Sphaeranthus amaranthoides, Hemidesmus indicus, Cyperus rotundus and Curcuma aromaticum. This paste can be applied in the axillary region as a deodorant.

\section{Podi (Powder)}

Powdered minerals and raw herbs are used as dusting powder and is applied over the wounds and ulcers $^{(3)}$.

\section{Therapeutic source}

Dry plant parts like leaves, flowers, Fermented rice water, salt, alum.

\section{Eligible criteria}

Podi is not advised in Infants, Allergic persons.

\section{Duration of the treatment}

The entire treatment is usually given for $6-12$ hours.

\section{Indications}

Fissures, Hemorrhoids, Skin ulcers, Gingivitis, Crack foot, Bleeding, Abscess, Wounds.

\section{Podi for various diseases ${ }^{(3)}$}

i. Powder of Alpinia officinarum is applied on the vertex after oil bath in infants to prevent the increase of Kapham.

ii. Thiripala powder is added with vinegar and applied on the soles for Peripheral Neuritis.

\section{Neer (Medicated Liquid)}

Raw drugs are soaked in water or made into decoction to concentrate or powerfully potent 
substances are greatly diluted and used to wash wounds. They are antiseptic solutions. This is prepared by either soaking the raw drugs in water and making a decoction of it or diluting the caustic substances ${ }^{(3)}$.

\section{Therapeutic source}

Dry plant parts like leaves, flowers, Fermented rice water, salt, alum.

\section{Eligible criteria}

Neer is not advised in Infants, Allergic persons.

\section{Duration of the treatment}

The entire treatment is usually given for 6 hours.

\section{Indications}

Fissures, Hemorrhoids, Skin ulcers, Gingivitis, Alopecia, Fistula, Eczema, Abscess, Wounds, Corn.

\section{Neer for various diseases ${ }^{(3)}$}

i. Decoction of Thiripala used in washing wounds, Eczema and non-healing ulcers. It is also used as gargle in Gingivitis and Oral ulcers. This is also used as douche for washing Uro-genital system, Ano-rectal diseases.

ii. $35 \mathrm{gms}$ of Alum is dissolved in 9 litres of water and filtered. This water is used as gargle on Stomatitis, as nasal drops to arrrest bleeding. This medicated water is also used for washing ulcers. iii. Borax is fried and dissolved in water and filtered, used for cleansing wounds.

\section{Nasal Application}

\section{Nasiyam (Nasal drops)}

It is a process by which the drug is administered through the nostrils. Fresh plants are cleaned thoroughly or blanched, crushed and juice extracted, filtered and instilled into the nostril. Individual oil or herbal juices or flower juices are also used for nasiyam ${ }^{(3)}$.

\section{Therapeutic source}

Fresh plant parts like leaves, stem, tuber, fruits or dry parts or fatty oil, alum.

\section{Eligible criteria}

Neer is not advised in below 7 years, after oil bath.

\section{Duration of the treatment}

The entire treatment is usually given for $30-45$ minutes.

\section{Indications}

Sinusitis, Common cold, Rigor, Fever, Chills, Body ache, Tremors, Convulsions, Septicemia, Headache, Scrotal swelling, Ascitis, Syncope.

\section{Nasiyam for various diseases}

i. The leaves of Ocimum sanctum (Kaattu thulasi), Leucas aspera (Thumbai), Vitex negundo (Notchi) shall be crushed individually with normal salt and the juice so obtained is instilled into

the nostrils. Nasiyam helps in eliminating the excess kapham and cures Headache, Sinusitis and Chest congestion ${ }^{(9)}$.

ii. Flowers of Leucas aspera are crushed and the juice is instilled in the nostrils for Fever with chills, Rigor and Parkinsonism ${ }^{(10)}$.

iii. Sulphur is triturated with Butter and spread uniformly on a cloth. This cloth is rolled over the tip of an iron rod and literally oil drops dripping from the flame is collected in a porcelain vessel, cooled and stored. 3 drops of this oil is instilled in the nostrils for ten days which heals Nasal polyps and Wounds ${ }^{(11) .}$

\section{Naasigabharanam (Insufflation)}

Insufflation is a common route of administration with many respiratory drugs used to treat conditions in the lungs (Asthma or emphysema) and Paranasal sinuses (allergy) ${ }^{(3)}$. 
Int. J. Curr. Res. Med. Sci. (2017). 3(7): 112-127

\section{Therapeutic source}

Fresh plant parts like leaves, flowers, dry powder like ginger powder, caustic stone powder, salt powder.

\section{Eligible criteria}

Naasigabharanam is not advised in infants.

\section{Duration of the treatment}

The entire treatment is usually given for $1-2$ minutes.

\section{Indications}

Sinusitis, Common cold, Rigor, Fever, Delirium, Eye diseases.

\section{Naasigabharanam for various diseases ${ }^{(12)}$}

i. Wild cow dung is soaked in the latex of Calotropis gigantea and dried. This process is repeated ten times and made into ash by calcination process. Ash is snuffed into nostril for treating Sinusitis.

ii. Tirikadugu podi is snuffed into nostril for treating Sinusitis.

\section{Oodhal (Blowing)}

Some Raw herbal leaves or medicines are chewed by the physician and the aromatic air is blown into the nose or ear of the patient as such or with the use of tools ${ }^{(3)}$.

\section{Therapeutic source}

Fresh plant parts like leaves, flowers, dry powder like ginger powder, caustic stone powder, salt.

\section{Eligible criteria}

Oodhal is not advised in Infants.

\section{Duration of the treatment}

The entire treatment is usually given for 3-10 minutes.

\section{Indications}

Sinusitis, Common cold, Rigor, Fever, Delirium, Eye diseases, Ear pain, Vertigo.

\section{Oodhal for various diseases(6)}

i. Chukku powder is blown in case of faintness in Varma injury.

ii. Vengayam is chewed and blown in the eyes of the patient suffering from Exanthemaotus fever.

\section{Ophthalmic Application}

\section{Mai (collyrium)}

Raw drugs is ground with Anjanakkal and leaf juices, it is then prepared into mai or waxy form by adding ghee. Mai is nothing but collyrium for the eyes ${ }^{(3)}$.

\section{Therapeutic source}

Plant parts like seeds, woods, bark or vegetable oil, cow's ghee, conch shell, pearl, anjanakkal.

\section{Eligible criteria}

Mai is not advised in infants, alcohol consumed persons, head injured persons, tuberculosis.

\section{Duration of the treatment}

The entire treatment is usually given for 3-12 hours of retaining period.

\section{Indications}

Sinusitis, Common cold, Rigor, Fever, Conjunctivitis, Alopecia, Menia, Xerophthalmia, Hoarseness of voice.

\section{Mai for various diseases ${ }^{(13)}$}

i. Equal quantities of the following materials are powdered separately and triturated with lime juice and rolled into pills, shade dried and stored Zingiber officinale (chukku), Piper longum (Thippili), Rock salt (Indhuppu), Allium sativum (vellai poondu), Barringtonia acutangula 
(samuthrapazham), Acorus calamus (vasambu). This pill is rubbed with the lime juice and applied as a Collyrium for treating convulsions as seen in Tetanus.

ii. Leaves of Punica granatum (Maadhulai) is baked with cow's milk and applied around the orbit to reduce the burning sensation of the eye.

iii. Saute Syzygium aromaticum (lavangam) leaves and flower and apply around the orbit for reducing the burning sensation of the eye.

\section{Kalikkam (Eye drops)}

Application of eye drops is called as Kalikkam. It is either applied in the form of herbal juices or by dissolving the medicated pills in honey ${ }^{(3)}$.

\section{Therapeutic source}

Fresh plant parts like leaves, stem, tuber, fruits or dry parts or fatty oil, alum.

\section{Eligible criteria}

Kalikkam is not advised in alcohol consumed persons, day sleep, after oil bath, on rainy days, physical exertion.

\section{Duration of the treatment}

The entire treatment is usually given for $30-45$ minutes.

\section{Indications}

Sinusitis, Common cold, Rigor, Fever, Conjunctivitis, Alopecia, Menia, Xerophthalmia, jaundice.

\section{Kalikkam for various diseases ${ }^{(12)}$}

i. Dry Zingiber officinale (chukku) is triturated with leaf juice of Piper betle (Vettrilai) and applied in the eye for Glaucoma.

ii. Leaf juice of Alternanthera sessilis (Ponankanni) is mixed with candy sugar (Karkandu)

and made into a paste by trituration. This paste is applied with the leaf juice of Piper betle (Vettrilai) in the eye and exposed to the medicated fumes to relieve Ophthalmalgia, blurred vision and burning sensation of the eye.

\section{Blood letting}

\section{Urinchal (Suction)}

Drainage of accumulated liquid such as pus, blood etc by suction. This technique is called Urinchal $^{(3) \text {. }}$

\section{Therapeutic source}

Surgical and para surgical instruments

\section{Eligible criteria}

Urinchal is not advised in Febrile, Shock, Cardiac cases, Haemophilia, Delirium, Contagious diseases.

\section{Duration of the treatment}

The entire treatment is usually given for $30-45$ minutes.

\section{Indications}

Abscess, Cysts, Carbuncle.

\section{Attai vidal (leech application)}

Leech application over affected areas of inflammation, blocks, etc. The leeches which are used therapeutically are not ordinary or dangerous ones. Hence the disease gets relieved. Leech application is usually done for hemorrhoids, contusions, swelling, tumours and ulcers. Leeches for this treatment should be maintained in healthy conditions in animal houses. To prevent cross infection, a separate set of leeches should be used for each patient ${ }^{(3)}$.

\section{Therapeutic source}

Medicinal leeches, turmeric, alum, salt, caustic calcium stone. 


\section{Eligible criteria}

Attai vidal is not advised in Infants, Cardiac cases, Haemophilia, Natural openings of the body, Allergic patients.

\section{Duration of the treatment}

The entire treatment is usually given for 10-15 minutes.

\section{Indications}

Heart diseases, Rheumatic diseases, Arthritis, Muscle tension, Varicose veins, Thrombosis, Embolism, Swelling, Eczema, Dysmenorrhoea, Contusion.

\section{Kuruthi vangal (Venesuction)}

This is a process of blood letting in the conditions where there is accumulation of toxic blood. In this type of treatment, a minor incision is made on the blood vessel and the excess blood is let out ${ }^{(3)}$.

\section{Therapeutic source}

Medicinal leeches, turmeric, alum, salt, caustic calcium stone, thiripala decoction.

\section{Eligible criteria}

Kuruthi vangal is not advised in Pregnancy, Tuberculosis, Anaemia.

\section{Duration of the treatment}

The entire treatment is usually given for 5-10 minutes.

\section{Indications}

Heart diseases, Rheumatic diseases, Arthritis, Muscle tension, Varicose veins, Thrombosis, Embolism, Swelling, Eczema, Dysmenorrhoea, Contusion, Hypertension.

\section{Bone setting}

\section{Murichal (Bone restructuring)}

This is a method of physical manipulation in which bone setting is done to correct the dislocation of bones ${ }^{(3)}$.

\section{Therapeutic source}

Dry powder, fatty oil, eggs, urine.

\section{Eligible criteria}

Murichal is not advised in Infants, Cardiac cases, Osteoporosis, Parathyroid.

\section{Duration of the treatment}

The entire treatment is usually given for 6-12 hours.

\section{Indications}

Bent bones, Dislocation.

\section{Kombukattal (Fracture splinting/ Immobilisation)}

This comprises of immobilizing fractured bone using splints and bandages - after proper reduction. Fracture management is still a thriving practice among traditional bone setters all over the world. Skilled bone setters identify fractures by simple touch and bring the fracture ends to position by simple physical manipulation in a fraction of a second.

\section{Therapeutic source}

Plant parts such as seeds, leaves, stems, eggs, horns.

\section{Eligible criteria}

Kombukattal is not advised in Infants, Pregnant women. 
Int. J. Curr. Res. Med. Sci. (2017). 3(7): 112-127

\section{Duration of the treatment}

The entire treatment is usually given for 3 or 7 to 21 days.

\section{Indications}

Knee swelling, Osteoporosis, Fracture, Dislocation.

\section{Physical Therapy}

\section{Thokkanam (Physical manipulation)}

This treatment may be defined as physical manipulation of body or the massage treatment which is either given to the entire body or a particular diseased part. Massage is done in two ways: First is just by using bare hands and second by using oil. There are 9 techniques used in this treatment.

a.Thattal b. Irukkal c. Pidithal d. Murukal e. Kaikattal f. Azhuthal g. Izhuthal h. Mallathuthal i. Asaithal.

Thokkanam is a method of manipulation and mobilization used primarily in the treatment of conditions related to changes in the varmam points leading to mechanical type of problems in joints and muscles ${ }^{(3)}$.

\section{Therapeutic source}

Medicated oils, decoctions, ghee, butter.

\section{Eligible criteria}

Thokkanam is not advised in Infants, Pregnant women, Post epileptic conditions, Unconscious persons.

\section{Duration of the treatment}

The entire treatment is usually given for 30-60 minutes.

\section{Indications}

Paralysis, Body pain, Arthritis, Disc diseases,Calcaneal spur, Myopathy, Autism, Insomnia, Sprain, Bell's palsy.

\section{Podithimirdhal (Massage with dry powder)}

The procedure of this therapy is rubbing the herbal powders over diseased part or throughout the body. This massage procedure is done in upward directions only ${ }^{(3)}$.

\section{Therapeutic source}

Plant parts such as seeds, leaves, stems, egg shell, dry powders.

\section{Eligible criteria}

Podithimirdhal is not advised in Jaundice, Infants, Alcohol consumed persons, Weeping eczema, Non-healing ulcers.

\section{Duration of the treatment}

The entire treatment is usually given for 30-45 minutes.

\section{Indications}

Sinusitis, Common cold, Obesity, Female infertility, Belly abdomen, Psoriasis, Psychiatric problems.

\section{Podithimirdhal for various diseases ${ }^{(3)}$}

i. The equal quantity of Manjal (Curcuma longa), Kollu(Macrotyloma uniflorum), Chunnambu, Omam (Trychyspermum ammi), are gently fried, powdered and mixed with camphor powder. It is massaged over skin to treat Kapham related diseases.

\section{Heat therapy}

\section{Vedhu (Steam therapy)}

Medicated steam exposure over the diseased part or throughout the body is termed as vedhu. The mechanism of Vedhu therapy is expelling out the wastes and impurities from the body via sweat glands.

\section{Therapeutic source}

Plants boiled in water, heated stones, blankets. 
Int. J. Curr. Res. Med. Sci. (2017). 3(7): 112-127

\section{Eligible criteria}

Vedhu is not advised in Infants, Pregnant women.

\section{Duration of the treatment}

The entire treatment is usually given for 10-15 minutes.

\section{Indications}

Sinusitis, Common cold, Swelling, Eczema, Dysmenorrhoea, Constipation, Paralysis, Oliguria, Body pain, Septicemia, Scrotal swelling, Dropsy, Hiccough, Arthritis, Insomnia, Psoriasis, Sprain.

\section{Vedhu for various diseases ${ }^{(7)}$}

i. Crush 416 gms each of the barks of Ficus benghalensis, Ficus religiosa in a pot and add sufficient quantity of water. This is boiled and vapour exposed to the ano-rectal region and also use the decoction along with the barks for washing the area twice a day in the morning and evening for 12 days to treat external hemorrhoids.

ii. Clerodendrum phlomidis (thazhuthalai), Calotropis gigantea (erukku), Vitex negundo (notchi) leaves are stir fried and added to vinegar. The resultant vapour is applied to the body after oleation and massage to cure vatha diseases of the joints particularly Rheumatoid arthritis.

\section{Pottanam (Medicated pouch)}

The raw herbs are ground and made into small pouches with bits of cotton cloth pieces. This medicated pouches are kept in the openings of the body like ear, nose and anus ${ }^{(3)}$.

\section{Therapeutic source}

Plant parts such as seeds, leaves, stems, nuts, grains, oils.

\section{Eligible criteria}

Pottanam is not advised in Infants, Pregnant women.

\section{Duration of the treatment}

The entire treatment is usually given for $15-20$ minutes.

\section{Indications}

Headache, Convulsions, Fever, Eye diseases, Measles, Delirium, Cervical Spondylosis, Ear ache.

\section{Pottanam for various diseases}

i. 670gms of Brassica nigra (kadugu) seed is taken in a cloth pouch with a string tied to its mouth. This pouch is soaked in warm Neem oil and after squeezing, the oil is pressed on the anterior fontanelle, posterior fontanelle, neck and the spinal joints for convulsive disorders and fever ${ }^{(14) .}$

ii. Sesame indicum (Ellu), Terminalia chebula (Kadukkai), Aegle marmelos (Vilvam), Ricinus communis (Aamanaku) are crushed and taken in a cloth pouch and the pouch is soaked in sesame oil and heated. This is used for fomentation over the eyelids for treating eye diseases with mild warmth $^{(13) .}$

\section{Suttigai (Cautery)}

This is otherwise called heat application. This type of application is usually done over vertex, forehead, chest, back, hands and legs.

There are 5 types of Suttigai:

1. Kaanthi suttigai- Sunbath

2. Kaatru suttigai- Exposure to blowing hot air

3. Mann suttigai- Suttigai with brick or earthen vessel

4. Mara suttigai- Suttigai with plant parts

5. Uloga suttigai- Metal cauterization

Kaatru suttigai - induces profuse sweating and helps removal of toxins from the body. This brings down excess pittham.

Mann suttigai - After spreading Vitex negundo (notchi ) leaf, an earthen pot in which oil was used earlier and applied on the vertex, forehead, chest, dorsum of torso and foot. This indirect heat application is done on delirium, toxaemia, muscular sprain. 
Mara suttigai - Among them mara suttigai is done with rhizome of turmeric plant (manjal kombu) and is indicated to treat the diseases like Sanni, Vaatha noi with Lock jaw, Kapha noigal, Virana silethuma noigal, peenisam, Anda vaayu, Vidhai veekam, muzhangal vatham and kuthikal Vatham. Uloga suttigai - For lymph node enlargement and tonsillitis, cauterisation is done with metal probes. The tip of the $1^{\text {st }}$ probe made of gold has a ring like shape with a hole at the centre, while the $2^{\text {nd }}$ one has a tip resembling a circular plate without a hole at the centre. The wound is healed with the application of Panchakini thylam ${ }^{(15) .}$

\section{Eligible criteria}

Suttigai is not advised in Infants, Pregnant women.

\section{Duration of the treatment}

The entire treatment is usually given for 3-5 seconds.

\section{Indications}

Delirium, Convulsions, Kapha diseases, Skin ulcers, Scrotal swelling, Anaemia, Hemorrhoids, Fistula, Abscess, Wounds, Jaundice, Deep ulcers, Carbuncle.

\section{Ottradam (Fomentation)}

Ottradam is the application of hot or cold packs. It is normally done with materials heated to appropriate temperature. While throwing out waste as toxins through the skin it also helps to disperse aggravated doshams, dilating all body channels for cleansing. Ottradam is classified into 2 types-hot and cold fomentation. It is the application of hot packs of pulses, cereals husk, lime, brick powder, leaves, etc. on or around the affected part for contusion and other swelling. Usually fomentation is used in Vaatha diseases. Equal quantity of the materials are crushed into a coarse powder and taken in a cloth bundle. This is saute with castor oil or medicated oil and fomentation is given ${ }^{(3)}$.

\section{Therapeutic source}

Plant parts such as leaves, pulses, cereals husk, lime, brick powder, egg- shell.

\section{Eligible criteria}

Ottradam is not advised in Infants, Pregnant women.

\section{Duration of the treatment}

The entire treatment is usually given for 15-30 minutes.

\section{Indications}

Headache, Convulsions, Fever, Eye diseases, Measles, Delirium, Cervical spondylosis, Ear ache, Arthritis, Lymphedema, Muscle spasm.

\section{Ottradam for various diseases ${ }^{(3)}$}

i. Leaves of medicinal plants like Vitex negundo (Notchi), Calotropis gigantea (Erukku), Ricinus communis (Aamanakku), Abutilon indicum (Thuthi) etc are tied in a cloth as a bundle.

This medicated bundle is heated and applied over the affected area. This type of treatment is very effective for Vatham ailments (Arthritis) and painful conditions like muscle cramps, bone disorders etc.

\section{Pugai (Fumigation)}

Fumigation denotes the artificial impregnation of the atmosphere, with the fumes or the smoke of any vegetable or aromatic substance. Fumes are also used as inhalation therapy. The process of fumigation with medicinal herbs under specific rituals influences widely the persons participating in it as well as the surrounding environment.

\section{Therapeutic source}

Plant parts like pepper, cumin, turmeric, sandal wood, neembark or vegetable oils like castor oil, neem oil, or aromatic substances like Sambirani (Styrax benzoin), Kukkil (Shorea robusta) or 
animal slough, egg shell, pearl, conch shell, feathers, horns and nails and few prepared

medicines like Vidakuzhambu, Agasthiyar kuzhambu, Kousigar kuzhambu. Fumigation

controls the infection upto the deeper area of the organs $^{(1)}$.

\section{Eligible criteria}

Fumigation with toxic substances is not advised in newborn, infants, pregnant and lactating women, people under influence of alcohol, suffering from head injury or lock jaw or Extreme dryness, Eye diseases, Anaemia, Bleeding disorders, Gonorrhoea $^{(3) .}$

\section{Duration of the treatment}

The entire treatment is usually given for 10-15 minutes for 7 days.

\section{Indications}

Sinusitis, Bronchitis, Ear diseases, Piles, Fistula, Chronic non-healing ulcers, Poisonous bites.

\section{Pugai for various diseases}

i. 20.48 gms of charcoal of Calotropis gigantea (Erukku), 5.12 gms each of Mercuric sulphide (Lingam), Corrosive sublimate (Veeram) and Mercury (Rasam), 10.24 gms of Shorea robusta (Kungiliyam) are triturated together with roots of Achyranthes aspera (Naaiyuruvi) are made into seven pouchs of a cloth soaked in the juice of Gossypium herbaceum (Paruthi). The pouch is burnt with charcoal of tamarind twigs and the patient is exposed to the emanating fume. Fumigation is done for seven times. It cures Vaatham diseases like Crippling aches and Pain including Colic, restriction of joint movements ${ }^{(16) .}$

\section{Surgical procedures}

\section{Aruvai (Excision)}

This is anatomical manipulation of any part of the using specific surgical instruments. The ideal time for surgical procedures is the morning. This is probably because that natural sunlight ensures precise treatment $^{(3)}$.

\section{Therapeutic source}

Surgical and para surgical instruments, 26 types of instruments explained by Agasthiyar.

\section{Eligible criteria}

Aruvai is not advised in Febrile, Shock, Cardiac cases, Haemophilia, Delirium.

\section{Duration of the treatment}

The entire treatment is usually given for 30-45 minutes.

\section{Indications}

Abscess, Neo-growths, Warts, Corns, Pile mass.

\section{Kaaram (Chemical Cautery)}

It is the method of application of Medicated Caustic drugs over areas of excision or chronic ulcers $^{(3)}$.

\section{Therapeutic source}

Metallic salts, turmeric, plant latex.

\section{Eligible criteria}

Kaaram is not advised in Hypertension, Infants, Allergic persons.

\section{Duration of the treatment}

The entire treatment is usually given for 5-15 minutes.

\section{Indications}

Skin ulcers, Fistula, Hemorrhoids, Corns, Abscess. 


\section{Kaaram for various diseases}

i. 20gms each of Blue vitriol (neelam) and yellow orpiment (Aridhaaram) and 80 gms of Shorea robusta (kungiliyam) are triturated with sesame oil, rinsed with fresh cool water and applied on a cotton cloth. This plaster is used to excise unwanted growth in external hemorrhoids, fistula, non-healing ulcers, granulomatous ulcers, abscess, toad skin and tumours with itching ${ }^{(15) .}$

\section{Keeral (Incision)}

In this method, an incision is made over the boils, abscesses, carbuncles, acne, etc so as to drain the accumulated pus, blood, water, etc out of them. Incision of boils and removal of accumulated pus, blood, etc. The instrument used for this is called $\mathrm{Kombu}^{(3)}$.

\section{Therapeutic source}

Sharp brow shaped long metal probe, cloth pieces.

\section{Eligible criteria}

Keeral is not advised in Infants, Cardiac cases.

\section{Duration of the treatment}

The entire treatment is usually given for 6-8 hours.

\section{Indications}

Carbuncle, Boils.

\section{Salaagai (Probe)}

This is application of a probe which is a slender apparatus made up of a metal used to trace out fistulous tracks. This is an exploratory therapy using a probe which has blunt end. The probe is used in Ophthalmic therapy particularly in the treatment of cataract. The probe is also used to explore deep seated abscess and introduce the medicated wick in fistula and sinus ulcer ${ }^{(15) .}$

\section{Therapeutic source}

Sharp brow shaped long metal probe.

\section{Eligible criteria}

Salaagai is not advised in Malignant growth, Allergic persons.

\section{Duration of the treatment}

The entire treatment is usually given for 10-15 seconds.

\section{Indications}

Skin ulcers, Fistula, Hemorrhoids, Corns, Abscess.

\section{Peechu (Douche)}

Peechu is the external therapy in which herbal decoctions or medicines are allowed to pass forcefully through openings like anus and vagina, though this therapy is used as a cleansing method, it also acts as a medicine in curing the disease.

\section{Therapeutic source}

Plant juices, salts, honey, fatty oil, ghee.

\section{Eligible criteria}

Peechu is not advised in Bleeding rectal cancer.

\section{Duration of the treatment}

The entire treatment is usually given for 6 hours.

\section{Indications}

Skin ulcers, Fistula, Hemorrhoids, Corns, Abscess, Constipation, Non-healing ulcers.

\section{Results and Discussion}

External medicinal applications are Gifts to Siddha, which need to be researched and practised with full concentration by all Siddha Doctors to make Siddha well flourished, welcomed and reached into the general population. It is our duty to expose our External therapy specialities like Varmam, Thokkanam, Kombu kattal, Vedhu, Pattru, etc. to modern world and other indigenous 
medicine world, so that the fame of siddha will be protected as well as propagated. It is very clear from the literature that the ancient physicians knew the connections between the brain and the sense organs and chose their routes and drugs accordingly. The physical therapies of Thokkanam, Varmam and most other therapies of Siddha are regaining popularity and efforts are on to validate and standardize the procedures. External therapies can be done in major measure with locally available resources and therefore is accessible as well as affordable.

\section{Conclusion}

This paper helps in giving Standard Operative Procedure towards Traditional therapies of Sidhha that have tremendous results in various diseases. The speciality of these Therapies lies therapeutic in nature. External therapies can be done in major measures with locally available resources and therefore is accessible as well as affordable to the entire society.

\section{References}

1. Thirunarayanan $T$. Introduction to Siddha Medicine, Chennai: Centre for Traditional Medicine and Research, 2012.

2. Thiyagarajan R, Gunapadam Thathu - Jeeva Vaguppu, Chennai: Directorate of India Medicine and Homoeopathy, $4^{\text {th }}$ edition, 1992

3. Thirunarayanan T, Sudha R. External therapies of Siddha Medicine, Chennai: Centre for Traditional Medicine and Research, 2010.

4. Uthamarayan K S. Siddha Maruthuvanga Churukkam, Chennai: Department of India medicine and Homeopathy, $3^{\text {rd }}$ edition, 2003.

5. Ramachandran S P. Theraiyar Vaidhiyam 1000, Chennai: Thamarai Noolagam, $1^{\text {st }}$ edition, 1999.

6. Venkatarajan S. Sarenbendirar vaithya Muraigal (Viranam, Karappan), Chennai: Thamarai Noolagam, $2^{\text {nd }}$ edition, 2004.

7. Pulippani Vaidhiyam 500, Central Research Institute for Siddha, Chennai 106, $1^{\text {st }}$ edition, 2009.

8. Kuppusamy Mudaliar K N. Siddha Vaidhiya Thirattu, Chennai: Department of Indian Medicine and Homeopathy, $1^{\text {st }}$ edition, 1998.
9. Thiyagarajan R. Theraiyar Tharu, Chennai: Research Institute of Siddha, 1997.

10. Anaivaari R. Anandan. Theraiyar Maha Karisal, Chennai: Department of Indian Medicine and Homeopathy, $1^{\text {st }}$ edition, 2009.

11. Ramachandran S P. Agasthiyar Paropooranam 1200, Chennai: Thamarai Noolagam, $1^{\text {st }}$ edition, 1997.

12. Ramachandran S P. Theraiyar Vaidhiyam 1000, Chennai: Thamarai Noolagam, $1^{\text {st }}$ edition, 1999.

13. Ramachandran S P. Agasthiyar Ayulvedham 1200, Chennai: Thamarai Noolagam, $1^{\text {st }}$ edition, 1999.

14. Kandasamy Mudaliar. Athma ratchamirtham Vaidhiya Sarasangiragam, Chennai: Sri Senbaga Pathippagam, $1^{\text {st }}$ edition, 2011.

15. Uthamarayan K S. Siddhar Aruvai Maruthuvam, Chennai: Department of Indian medicine and Homeopathy, $4^{\text {th }}$ edition, 2005.

16. Ramachandran S P. Agasthiyar Rana Vaidhiyam, Chennai: Thamarai Noolagam, $2^{\text {nd }}$ edition, 2000.

\begin{tabular}{|c|c|}
\hline \multicolumn{2}{|c|}{ Access this Article in Online } \\
\hline 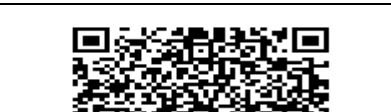 & $\begin{array}{l}\text { Website: } \\
\text { www.ijcrims.com }\end{array}$ \\
\hline 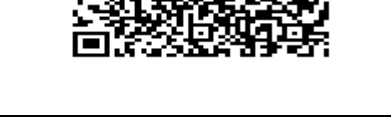 & $\begin{array}{l}\text { Subject: } \\
\text { Siddha Medicine }\end{array}$ \\
\hline Quick Response Code & \\
\hline
\end{tabular}

How to cite this article

S.Mohamed Ajmal, M.Naga lakshmi, M.Nandhini, G.Meenadharshini, P.J.Kowshika shree, T.Keerthiga, A.P.Uma. (2017). Standard Operative Procedure on External therapies in Siddha system of medicine. Int. J. Curr. Res. Med. Sci. 3(7): 112-127.

DOI: http://dx.doi.org/10.22192/ijcrms.2017.03.07.018 